\title{
Transparent, Black and Organic Mulches Effect on Weed Suppression in Green Pepper (Capsicum annuum) in Western Kenya
}

\author{
Ocharo N. Edgar (Corresponding author) \\ Department of Agricultural Science and Technology, Kenyatta University, Kenya \\ KEPHIS-Kenya Plant Health Inspectorate Services, P.O Box 49592-00100, Nairobi, Kenya \\ Tel: 254-721-447-697Ｅ-mail: ocharoedgar@yahoo.com \\ Joseph P. Gweyi-Onyango \\ Department of Agricultural Science and Technology, Kenyatta University \\ P O Box 43844-00100 Nairobi, Kenya
}

Tel: 254-714-795-463Ｅ-mail: josephonyango2002@yahoo.co.uk, gweyi.joseph@ku.ac.ke

\section{Nicholas Kibet Korir}

Department of Agricultural Science and Technology, Kenyatta University,

P O Box 43844-00100 Nairobi, Kenya

Tel: 254-703-815-426Ｅ-mail: kibetnicholas@gmail.com, korir.nicholas@ku.ac.ke

Received: January 9, 2017 Accepted: January 22, 2017 Published: February 24, 2017

doi:10.5296/jas.v5i1.10807

URL: http://dx.doi.org/10.5296/jas.v5i1.10807

\begin{abstract}
Weed suppression through physical methods in cultivation constitutes of many methods but this experiment focused on application of various mulches. Recently, herbicide-free weed control methods in the world are getting more attention due to environmental and ecological factors. Green pepper production requires good management practices in order to attain potential yields. Most of the known physical practices of weed control cause both positive and negative effects. Therefore, great attention should be paid when selecting the appropriate mulch with the aim of weed suppression in any specific cultivation. Three types of mulches
\end{abstract}


were examined for weed control namely; black plastic mulch, transparent plastic mulch, straw mulch and bare soil as control during the 2015 short and long raining seasons in Busia County. In both seasons, the black plastic mulch treatment significantly $(\mathrm{P}<0.05)$ showed the lowest number of weed species (3) per $\mathrm{m}^{2}$ quadrat while the control had the highest with a maximum of 8 and 7 during the long and short raining seasons respectively. The number of species reduced after four weeks from transplanting when the first sampling was carried out. The lowest weed vigor was exhibited in the plastic treatments for both seasons at 4, 6 and 8 weeks after transplanting. Control had the highest weed fresh biomass for both seasons at all the sampling stages with the highest observed during the short raining season with $1626 \mathrm{~g} / \mathrm{m}^{2}$ at 4 weeks after transplanting. This also translated to the highest weed dry biomass for both seasons in the control plots with the lowest recorded in the black plastic mulch. Out of several physical methods of weed control, mulching seems to be the most appropriate with the black plastic mulch being the best.

Keywords: Herbicide free, ecological factors, quadrat, biomass

\section{Introduction}

Weeds reduce crop productivity by interfering with crop growth and are responsible of the highest potential loss in the most important crops worldwide. Reduction of yield by about $40 \%$ in maize and $84 \%$ in upland rice (Akobundu, 1987) was reported due to uncontrolled weeds, while 31-70\% in groundnut (Lagoke et al., 1981), and between 73-78\% in cayenne pepper (Awodoyin \& Ogunyemi, 2005). Uncontrolled Imperata cylinderica (L.) resulted in $92 \%$ reduction in maize grain yield in the drier savanna zone of Nigeria (Akobundu and Ekeleme, 2001). Apart from reducing crop yield, weeds contaminate and taint farm product hence reduce their market values and change their end use. Weed control plays a major role in pre-harvest production costs where it requires more labor which limits the land area a farmer could cultivate at any given time (Chianu \& Akintola, 2003). Also Akobundu (1987) reported that labour requirement for weeding as a percentage of total labor needed for crop production (harvesting inclusive) is $30 \%$ for maize, $37 \%$ for sorghum, 25\% for cassava and $22 \%$ for white yam. Usoroh (1983) reported that weeding alone takes 30-45\% of total cost of labour required for fruit and vegetable production. Chianu and Akintola (2003) reported that weeding demands 32.1-45.0\% of total labor input under bush fallow, 32.3-38.4\% under cover cropping and $24.1-35.4 \%$ under alley cropping.

Mulching is an effective method of manipulating crop growing environment to increase yield and improve product quality by controlling weed growth, ameliorating soil temperature, conserving soil moisture, reducing soil erosion, improving soil structure and enhancing organic matter content (Opara-Nadi, 1993; Hochmuth et al., 2001). Awodoyin and Ogunyemi (2005) have reported that the weed control efficiency of different types of mulch in cayenne pepper production ranged from $27 \%$ to $97 \%$. An advantage of using mulches is the fact that when mechanical or manual weeding is not needed, root damage of crop plants is minimized (Brault et al., 2002).

Weeds compete for space, light, water and nutrients, weakening crop stand and reduce harvest efficiency and therefore reducing crops yields (Abbasi et al., 2013). Although weed 
control has always been an important component of green pepper production, its importance has not been well researched and documented in Kenya and this has led to a drop in the yields of the crop. Green pepper cultivation is still under small scale cultivation that supplies local markets in the country as a small fraction goes for export. Considering the crops high nutritive value and the export potential successful cultivation should be attempted (HCDA, 2010). As much as herbicides can be effective in controlling weeds, they are also expensive and often beyond the budget of farmers in developing countries like Kenya. Also, herbicide use necessitates particular equipment and expertise to ensure that proper rates are used and that human health and safety are protected. Mulching is a current and important non-chemical weed control method and led to the current study to evaluate the efficacy of the black plastic, transparent plastic and straw mulch on weed control.

\section{Materials and Methods}

\subsection{Study Site}

The study was carried out in the experimental field at Kenya Agricultural and Livestock Research Organization (KALRO), Alupe Crops Station in Busia County during the long rain season (March to August) and short rain season (September to December). The study was specifically carried out in the southern block part of the land. The topography of the land was generally flat with slight undulation. It lies within latitude $0^{\circ} 30^{\prime} \mathrm{N}$, longitude $34^{\circ} 07^{\prime} \mathrm{E}$ with an elevation of $1157 \mathrm{~m}$ above sea level. The soil in this area was observed to be sandy loam with moderate porosity and moderate water retention ability. The land used for the study was under sorghum and fallow for the previous seasons respectively before the experiment. The area was dominated by a mixture of Wondering Jew, Mexican marigold and Amaranthus spp. The rainfall pattern was bimodal with peaks in June and October. The total rainfall was less in the short rain season $(569.6 \mathrm{~mm})$ than the long rain season $(705.4 \mathrm{~mm})$. The mean relative humidity and average annual air temperature were respectively $76.9 \%$ and $24.1^{\circ} \mathrm{C}$ in the long rain, and $78.9 \%$ and $23.7^{\circ} \mathrm{C}$ in the short rain.

\subsection{Cultural Practices}

The site which was previously cropped with sorghum was prepared for planting by clearing using cutlasses in March, 2015. At two weeks after clearing, stumps and debris were removed from the experimental area. This was followed by lining and pegging of the area into blocks and plots. Both blocks and plots were separated by a $1 \mathrm{~m}$ buffer. The nursery area was cleared using a cutlass and a nursery box of $3 \mathrm{~m}$ length, $2 \mathrm{~m}$ width and $20 \mathrm{~cm}$ height prepared and then a shed erected over the nursery box. The green pepper variety used for the study (California wonder) was obtained from an Agro-dealer in Malaba Town and sown in drills of $10 \mathrm{~cm}$ apart on February 2015 for the long rain season planting and in August for the short rain season planting. Rain was alternated with watering in the evening hours up to the time of transplanting. Seedlings were fertigated with $20 \mathrm{~g}$ of NPK dissolved in 2 litres of water weekly. As a preventive measure against pests, grasshoppers and crickets, seedlings were sprayed with Cidym Super fortnightly.

Uniform seedlings of height $15 \mathrm{~cm}$ with 3 to 5 leaves were transplanted with planting 
distance of $40 \mathrm{~cm} \times 40 \mathrm{~cm}$ on plots that measured $3.0 \mathrm{~m} \times 2.0 \mathrm{~m}$. The plants were side-dressed with NPK fertilizer at the rate of $100 \mathrm{~kg} / \mathrm{ha}$ in two splits; one-half at two weeks after transplanting and another one-half two weeks later. The plants were side-dressed again with Urea at the rate of $10 \mathrm{~kg} / \mathrm{ha}$ at flowering. The plants were irrigated uniformly depending on the soil and climate conditions so as to maintain adequate moisture in root zone in open field conditions.

\subsection{Experimental Design and Application of Treatments}

The three mulching treatments namely black plastic mulch $(0.25 \mu \mathrm{m})$, transparent plastic mulch $(0.25 \mu \mathrm{m})$, straw (sourced from Finger millet) and the control treatment (bare soil) were arranged in a randomized complete block design (RCBD) and replicated three times. The plastic and straw mulches were laid just before transplanting. Transplanting holes were made at pre-marked points on the plastic mulches and straw mulches were applied to $2 \mathrm{~cm}$ thickness.

\subsection{Data Collection}

The number of weed species in every experimental unit was counted and recorded at every weeding for three samplings. The vigor of weeds was recorded from each experimental unit at every weeding using the scale of 1-3 where 1 was most vigorous, 2-intermediate and 3-poor after four weeks after transplanting and after two weeks thereafter. Weight of fresh weeds taken from randomly thrown quadrat of $1 \mathrm{~m}^{2}$ (three times) on each experimental plot before weed control at 4 weeks after transplanting and recorded in grams. The weed biomass was weighed using an electric weighing scale. The fresh weeds collected from the quadrat were oven-dried at $80^{\circ} \mathrm{C}$ for 48 hours and weighed with a digital balance (model P1210) to determine the weed dry weight.

\subsection{Data Analysis}

Data on the weed parameters were analyzed using Analysis of Variance (ANOVA) for randomized complete block design (RCBD) using SAS version 9.0. Fischer's least significance difference (LSD) test at $\mathrm{P} \leq 0.05$ was used to compare the means.

\section{Results and Discussion}

\subsection{Weed Species}

Significant differences $(\mathrm{P}<0.05)$ were observed between the mulch treatments on the number of weed species per plot in all the weeding regimes for both seasons. The number of weed species was highest in the control for both seasons during all the sampling stages (Fig. 1). The weed species reduced as the crop growth advanced from four weeks to eight weeks after transplanting. Marana et al. (1986) also estimated that the critical period of weed competition to be 30-40 days after seeding; therefore, they suggested that weeds should be removed for 40-50 days after sowing and similar findings were shown in the current study. The above authors further emphasized that the presence of weeds reduced fruit yield by $70 \%$ subject to the stage and duration of competition. Shadbolt and Holm (1956) also concluded from their studies that the first four weeks were critical in many vegetable crops, during which time 
weeds should be removed. The lowest number of weed species was observed on the plastic mulches for the two seasons. The weed species observed were Tradescantia fluminensis, Galinsoga parviflora, Oxalis latifolia, Amaranthus spp, Tagetes minuta and Bidens pilosa. During the short rain season, the control plots showed a maximum of 8 weed species in an area of $1 \mathrm{~m}^{2}$. Therefore, this indicates that the competitiveness of green pepper with weeds can be improved through the use of black plastic polythene as mulch. It is also well established that a kilogram of weed biomass in a field corresponds to the loss of a kilogram of a given yield of crop (Rao, 2000). The reduced number of weed species on the black plastic led to the enhancement of the subsequent yield, indicating that the weeds were effectively controlled through the shadowing of the covered weeds restricting them to perform photosynthesis that reduced their competitiveness. The black plastic not only physically barred the perennial weeds from emerging and growing but also the underground propagules were suffocated because of increased temperature and reduced light availability. It has been reported that the yield losses in crops occur due to biomass and density of weeds (Mamolos \& Kalburtji, 2001).

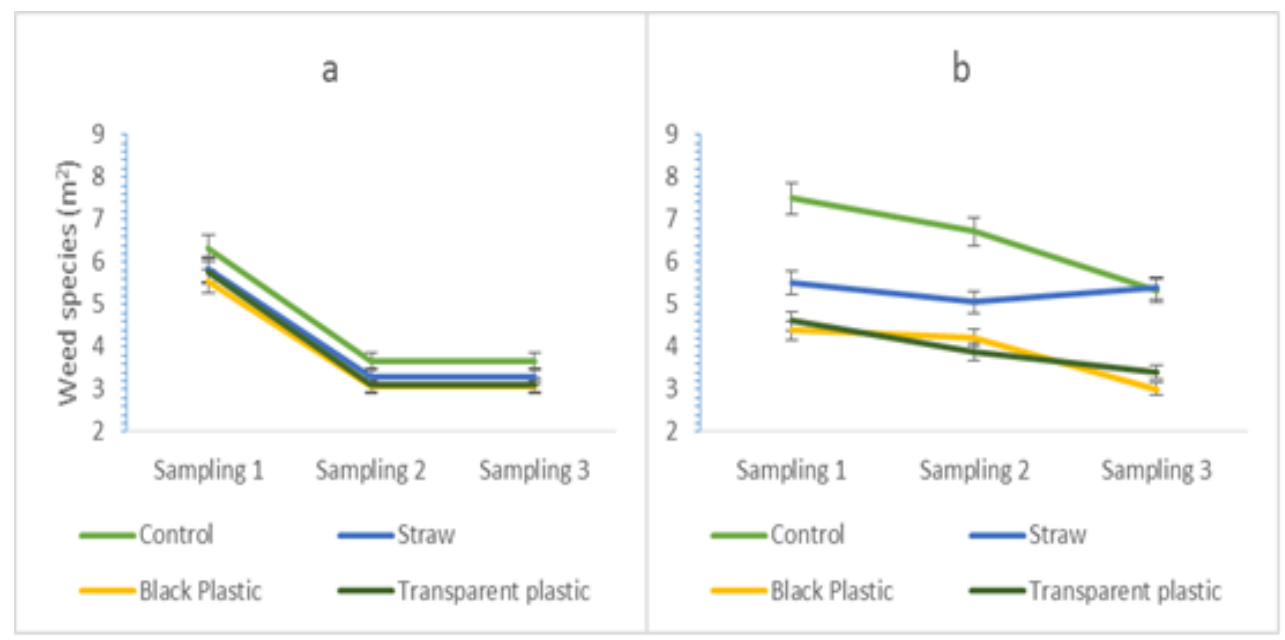

Figure 1. The number of weed species per metre squared during the long rain season of March - August (a) and short rain season of September - December (b) in Busia, Kenya in 2015

\subsection{Weed Vigor}

The weed vigor was greatest on the control for both seasons at four weeks after transplanting and closely followed by the straw mulch treatment (Table 1). The least weed vigor was observed in the plastic treatments with the black showing the poorest growth of weeds. The same trend was observed at eight weeks after transplanting. The use of mulch probably enhanced microbial activity in soil by improving soil agro-physical properties and therefore suppressed weed growth (Iruthayaraj et al., 1989). All the stages for both seasons showed significant differences between the mulch treatments on the weed vigor score. The black plastic polythene is more effective in increasing crop yield compared to the other mulching materials, indicating that the weeds were better controlled through the covering of weeds through the mulch's shadow disabling them to execute photosynthesis reducing greatly their 
competitiveness with the green pepper crop. This findings conforms to earlier reports of black plastic polythene mulch in weed control by Hartmann et al. (1981) and Olabode et al. (2006) where the latter worked on Okra plants. Govindra et al. (1986) observed that weeds caused a $57 \%$ reduction in tomato yield when compared with weed free conditions. Adigun (2002) also reported that uncontrolled weed growth during the crop life cycle resulted in 92 to $95 \%$ decline in tomato fruit yield.

Table 1. The mulching materials influence on the weed vigor during the long rains of March August and short rains of September - December 2015 in Busia, Kenya

Weed Vigor 4 WAT Weed Vigor 6 WAT Weed Vigor 8 WAT

\begin{tabular}{lllllll}
$\begin{array}{l}\text { Mulch } \\
\text { Treatment }\end{array}$ & Long Rain & $\begin{array}{l}\text { Short } \\
\text { Rain }\end{array}$ & Long Rain & $\begin{array}{l}\text { Rain } \\
\text { Lang Rain }\end{array}$ & $\begin{array}{l}\text { Short } \\
\text { Rain }\end{array}$ \\
\hline Control & $1.389^{\mathrm{a}}$ & $1.278^{\mathrm{a}}$ & $1.444^{\mathrm{a}}$ & $1.167^{\mathrm{a}}$ & $1.444^{\mathrm{a}}$ & $1.556^{\mathrm{a}}$ \\
Straw & $1.889^{\mathrm{b}}$ & $1.444^{\mathrm{b}}$ & $1.667^{\mathrm{ab}}$ & $1.611^{\mathrm{b}}$ & $1.778^{\mathrm{b}}$ & $1.694^{\mathrm{b}}$ \\
Black & $2.889^{\mathrm{d}}$ & $2.889^{\mathrm{c}}$ & $1.944^{\mathrm{b}}$ & $2.671^{\mathrm{c}}$ & $2.667^{\mathrm{d}}$ & $2.056^{\mathrm{d}}$ \\
Transparent & $2.056^{\mathrm{c}}$ & $2.111^{\mathrm{c}}$ & $1.722^{\mathrm{ab}}$ & $1.765^{\mathrm{b}}$ & $2.111^{\mathrm{c}}$ & $1.889^{\mathrm{c}}$ \\
P Value & & $<\mathbf{0 . 0 0 1}<\mathbf{0 . 0 0 1}$ & $\mathbf{0 . 0 4 8}$ & $<\mathbf{0 . 0 0 1}$ & $<\mathbf{0 . 0 0 1}$ & $\mathbf{0 . 0 0 4}$ \\
\hline
\end{tabular}

Different letters within each column refer to statistically significant differences according to Fischer's LSD mean separation test at $\mathrm{P}<0.05$, WAT-Weeks after transplanting

\subsection{Fresh Weed Biomass}

The control plots had the highest weed fresh biomass in all the sampling stages for both seasons (Fig. 2). The highest biomass was recorded at four weeks after transplanting on the control plot with a mean of $1629 \mathrm{~g} / \mathrm{m}^{2}$. The black plastic elicited the lowest fresh biomass of weeds for both seasons in the three sampling periods. The transparent plastic was the second most efficient material in the suppression of weeds growth. Black mulch effectively reduced weed growth by intercepting nearly all-incoming radiation. It has been found that it is essential to cover the soil surface with different materials to attain high biological activity, preserve soil moisture and to achieve a good control of weeds under the black plastic whereas clear mulch absorbs only $5 \%$ of short-wave radiation, reflects $11 \%$, but transmits $84 \%$ of it (Aman \& Rab, 2013). Only the long rains season on the first stage of weeding did indicate insignificant influence of the mulch treatments on the weed fresh biomass. During the first weeding the control had the highest amount of fresh biomass weight during both seasons. The transparent polythene mulch had the highest fresh weed biomass during the second weeding while the organic mulch did indicate the greatest mass of fresh weeds per plot during the last period of weeding. Yield losses in crops occur due to accumulation of weed biomass and weeds density. 


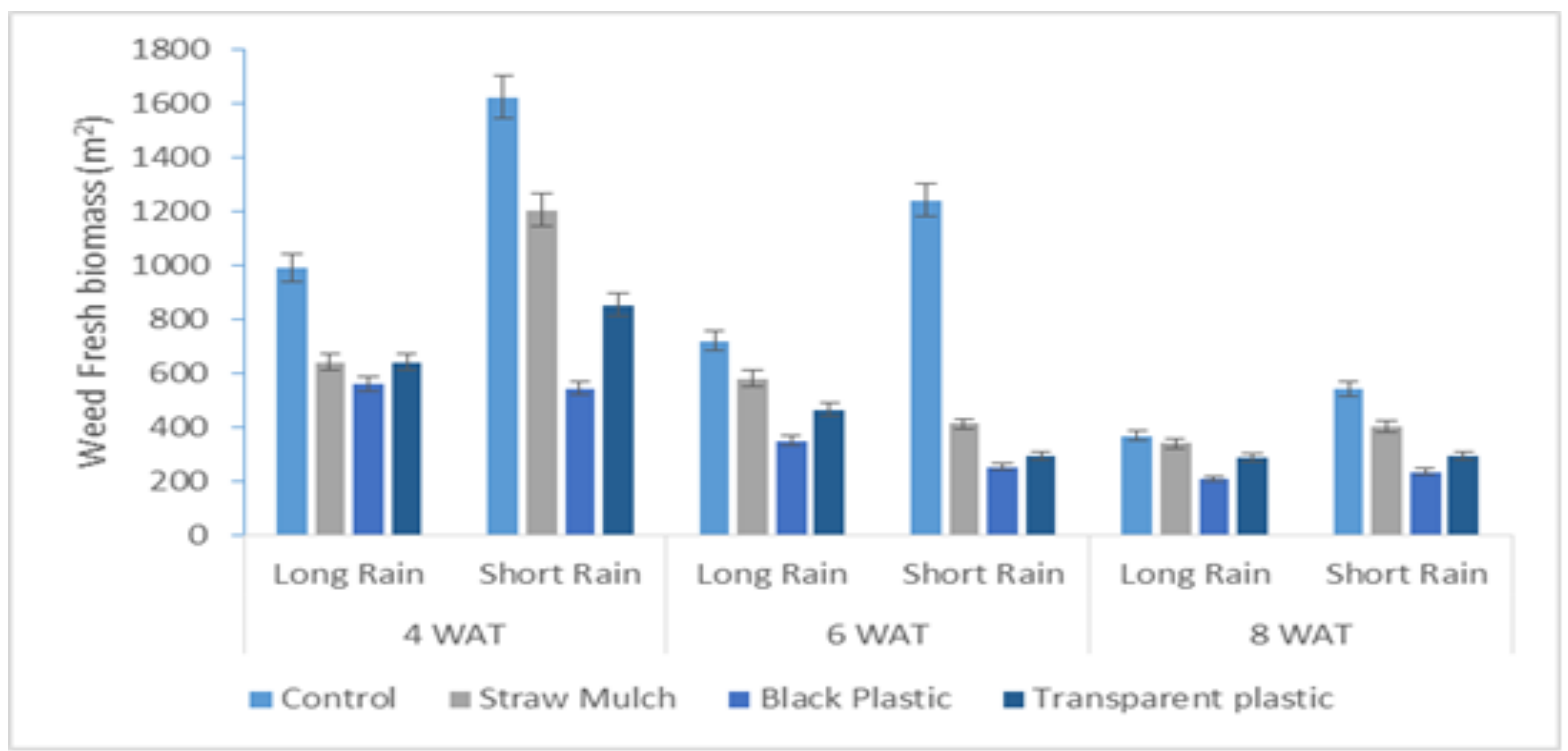

Figure 2. The weed fresh, above ground, biomass during the long raining season of March August and short raining season of September - December 2015 in Busia, Kenya under different mulching materials

\subsection{Weed Dry Biomass}

All the weeding stages showed significant influence of the mulch treatments on the dry biomass of weeds for both seasons (Fig. 3). The control had the highest dry biomass while the straw mulch elicited the second highest dry weed biomass. The weeds lost more than $60 \%$ mass after drying where the black plastic mulch had the lowest dry biomass at all the weeks of sampling followed by the transparent plastic mulch.

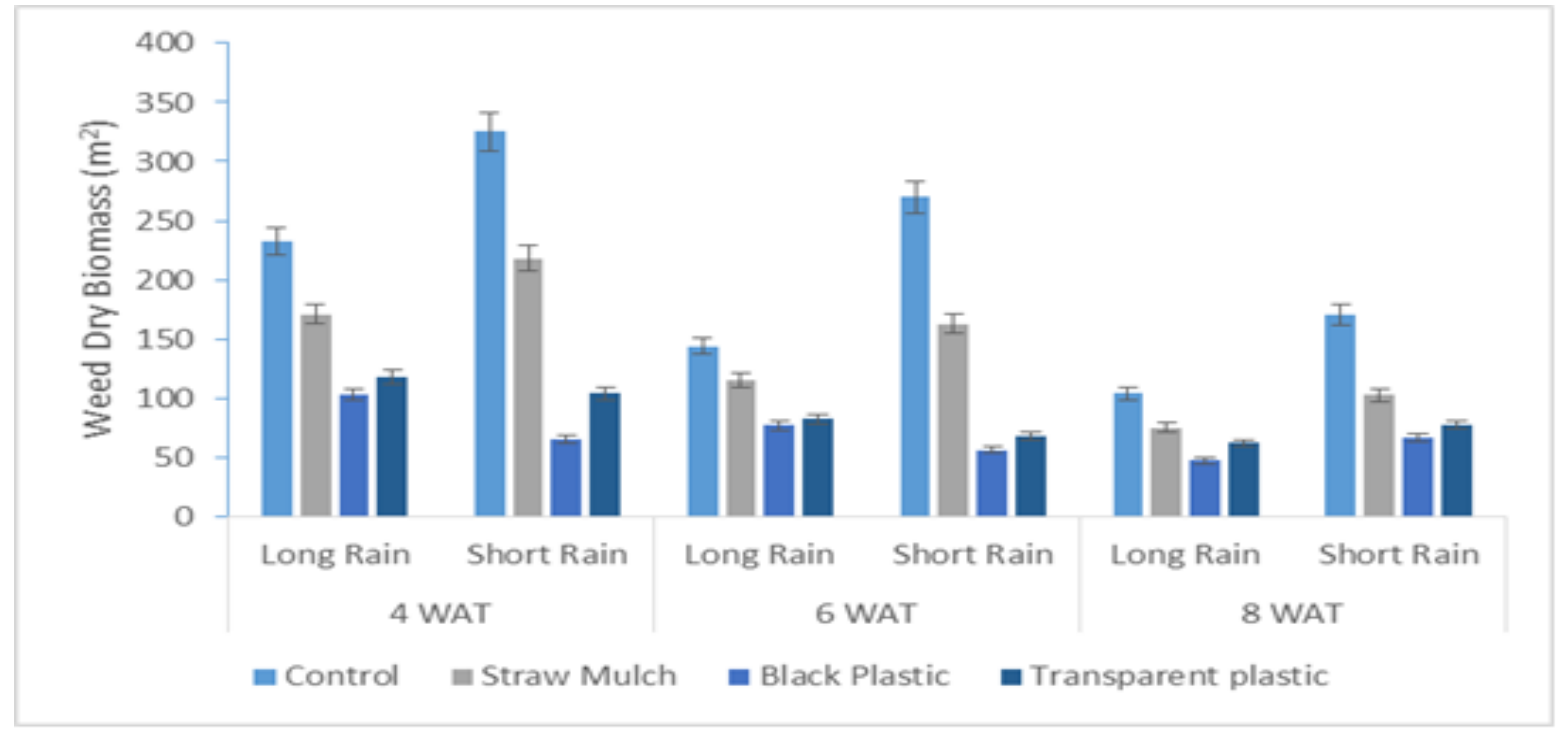

Figure 3. The weed dry, above ground, biomass during the long rains of March - August and short raining season of September - December 2015 in Busia, Kenya under different mulching materials 
By providing a physical barrier, mulching reduced the germination and nourishment of many weeds and if somehow the weeds grow, they become pale and ultimately die or have weak growth and development. Pimpini (1974) established that the plastic mulches benefitted crops with black and photo selective plastic being preferable to the transparent type in eggplant for weed control. The mulches favored the reduction of evaporation which led to higher soil moisture content, reduced weed growth and the decomposition of added mulches might also have contributed to increase in the supply of nutrients and moisture for the overall increase in crop yield. Layering or mulching the soil surface prevented weed seed germination and physically suppressed the seedling emergence. In another study by Ossom et al. (2003), it was reported that white and green covering had petite effect on weeds, whereas brown, black, blue or white on black films significantly reduced emergence of weeds. Daisley et al. (1988) also observed significant differences in weed control between mulched and unmulched plots of eggplant, cowpea and sweet potato.

\section{Conclusion}

Weed control is necessary in transplanted green pepper crop to obtain benefits. Synthetic mulches, especially black plastic film, effectively suppressed most weeds growth, thereby reducing labor and other costs for weed control. The opaque film reduced germination of light-responsive weed seeds; shaded out and physically blocked the emergence of most weeds; and can enhance crop growth by reducing competition, conserving soil moisture, promoting soil warming, and speeding nutrient mineralization from soil organic matter. The crop growth benefits contribute to weed management by enhancing the crop's ability to tolerate and compete with weeds and leads to higher yields and better quality fruits

\section{Acknowledgement}

The authors specially thank the valuable technical assistance of the staff and casual workers at the KALRO-Alupe Research Station for their help during the project period for their technical assistance and supervision.

\section{References}

Abbasi, N. A., Zafar, L., Khan, H. A., \& Qureshi, A. A. (2013). Effects of naphthalene acetic acid and calcium chloride application on nutrient uptake, growth, yield and post-harvest performance of tomato fruit. Pak. J. Bot., 45(5), 1581-1587.

Adigun, J. A. (2002). Chemical weed control in transplanted rainfed tomato (Lycopersicon esculentum Mill) in the forest-savanna. Transition zone of south western Nigeria. Agric. Environ, 2(2), 141-150.

Akobundu, I. O. (1987). Weed Science in the Tropics: Principles and Practices. John Wiley and Sons, Chicester, UK, 522 pp. https://doi.org/10.1017/s0266467400003369

Akobundu, I. O., \& Ekeleme, F. (2001). Effects of methods of Imperata cylindrica manage-ment on maize grain yield in the derived savanna of southwestern Nigeria. Weed Research, 40, 335-341. https://doi.org/10.1046/j.1365-3180.2000.00194.x 
Aman, S. \& Rab, A. (2013). Response of tomato to nitrogen levels with or without humic acid. Sarhad J. Agric., 29(2), 181-186.

Awodoyin, R. O., \& Ogunyemi, S. (2005). Use of sicklepod, Senna obtusifolia (L.) Irwin and Barneby, as mulch interplant in cay-enne pepper, Capsicum frutescens L., production. Emirate Journal Agricultural Science, 17(1), 10-22. https://doi.org/10.9755/ejfa.v12i1.5044

Brault, D., Stewart, K. A., \& Jenni, S. (2002). Optical properties of paper and polyethylene mulches used for weed control in lettuce. HortScience, 37, 87-91.

Chianu, J. N., \& Akintola, J. O. (2003). Labour needs for weeding: Implications for the adoption of improved fallow management systems in the derived savannas of south-western Nigeria. Nigerian Journal of Weed Science, 16, 1-7

Daisley, L. E. A., Chong, S. K., Olsen, F. J., Singh, L., \& George, C. (1988). Effects of surface-applied grass mulch on soil water content and yields of cowpea and eggplant in Antigua. Tropical Agriculture (Trinidad), 65, 300-304

Govindra, S., Bhan, V. M., \& Tripathi, S. S. (1986). Effect of herbicide alone and combination with weeding on tomato and associationated weeds. Indian J. Weed Sci., 16(4), 262-266.

Hartmann, H. T., Kofranek, A. M., Rubatzky, V. E., \& Flocker, W. J. (1981). Plant Science. Growth, Development and Utilization of cultivated plants, 2nd ed. Prentice-Hall, Inc. Simon and Schusfet, Englewood Clif fs, New Jersey. https://doi.org/10.1086/412860

Hochmuth, G. J., Hochmuth, R. C., \& Olson, S. M. (2001). Polyethylene Mulching for Early Vegetable Production in North Florida. University of Florida/Institute of Food and Agricultural Sciences (UF/IFAS), Florida A \& M University Cooperative Extension Programme.

HCDA Horticulture Report. (2010). Horticultural Crops Development Authority. Horticultural Annual Report.

Iruthayaraj, M. R., Krishnamurthi, V. V., \& Rangasamy, A. (1989). Effect of mulching pattern in maize on water economy and weed control. Madras Agric. J., 76, 474-476.

Lagoke, S. T. O, Choudary, A. H., \& Tanko, Y. M. (1981). Weed control in rainfed groundnut in the savanna zones of Nigeria. Weed Research, 21, 11-25. https://doi.org/10.1111/j.1365-3180.1981.tb00105.x

Marana, J., Gongora, R., Paredes, E., \& Labrada, R. (1986). Critical period of competition from weeds in direct sown tomatoes. Tech. Agric. Hort, 2(1), 73-83.

Mamolos, A. P., \& Kalburtji, K. L. (2001). Competition between Canada thistle and winter wheat. Weed Sci., 49(6), 755-759. https://doi.org/10.1614/0043-1745(2001)049[0755:cbctaw] 2.0.co;2

Olabode, O. S., Ogunyemi, S., \& Awodoyin, R. O. (2006). Response of okra (Abelmosch us esculentus (L.) Moench) to weed control by mulching. Ghana Journal of Agricultural 
Science, 39(1), 35-40. https://doi.org/10.4314/gjas.v39i1.2124

Opara-Nadi, O. A. (1993). Effect of elephant grass and plastic mulch on soil properties and cowpea yield. In: Mulongoy, K. and Merckx. R. (eds.), Soil Organic Matter Dynamics and Sustainability of Tropical Agriculture. John Wiley \& Sons, New York. P, 351-360.

Ossom, E. M., Pace, P. F., Rhykerd, R. L., \& Rhykerd, C. L. (2003). Influence of mulch on soil temperature, nutrient concentration, yield components and tuber yield of sweet potato (Ipomea batatus). Indian Journal of Agricultural Sciences, 73, 57-59. https://doi.org/10.4314/uniswa-rjast.v6i2.4737

Pimpini, F. (1974). Chemical weed control in a semi-forced crop of gladiolus. Rivista di Agronomia, 8, 335-343. https://doi.org/10.1111/j.1365-3180.1974.tb01072.x

Rao, V. S. (2000). Harmful effects caused by weeds. Principles of Weed Science. Oxford and IBH publishing Co. Pvt. Ltd.New Delhi \& Calcutta, Pp. 1.

Shadbolt, C. A., \& Holm, L. B. (1956). Effect of weed on several vegetable crops. Weeds, 4, 111-123. https://doi.org/10.2307/4039983

Usoroh, N. J. (1983). Weed problems and control strategies in fruit and vegetable production in Nigeria. Acta Horticulturae, 123, 299-304. https://doi.org/10.17660/actahortic.1983.123.27

\section{Copyright Disclaimer}

Copyright for this article is retained by the author(s), with first publication rights granted to the journal.

This is an open-access article distributed under the terms and conditions of the Creative Commons Attribution license (http://creativecommons.org/licenses/by/4.0/). 